\title{
Scholarly Strains on Shaky Ground: Caribbeanness and the Campus in Marking Time and Grounds for Tenure
}

\author{
Jarrel De Matas \\ University of Massachusetts, US \\ dematasj@gmail.com
}

Campus narratives, either written by Caribbean writers or whose setting is the Caribbean, explore issues that go beyond the affairs of the institution. This paper focuses on two particular works of Campus fiction, E.A. Markham's Marking Time (1999) and Barbara Lalla's Grounds for Tenure (2017), which - despite being published almost two decades apart - interrogate aspects of the university on their way to raising questions about Caribbean identity in the region and its overseas diaspora. These questions revolve around the frail interpersonal relationships between academics; the rivalries that ensue out of the quest for power; the politics that undermine the duty of the university; and the psychological ruptures that result from pursuing tenureship in an academic rat race. The primary argument made in this paper is that each novel reflects ideological statements about the Caribbean and its diaspora that are both internally as much as externally produced. By incorporating the wider world into the affairs of the campus, the novels demystify the esteemed position of Caribbean institutions when faced with larger, neo-liberal systems at work.

Apart from the internal missteps of the university being explored by each novel, there is also the larger exploration of the effects on the institution brought on by the commercialization of higher education. By using satire, both writers dramatise controversy in extreme cases and thereby allow serious consideration of the function of the contemporary Caribbean university. Both novels help us to understand not only educational institutions in crisis, but also different stages of crises that stem from being Caribbean.

Keywords: Campus Novel; Caribbean Literature; Caribbeanness; E.A. Markham; Barbara Lalla

Academic institutions, beyond the outward appearance of stability, pride, loftiness, and diversity can be highly fragile, pretentious, unexceptional, and exclusive. The campus novel is a nuanced genre that is specifically attuned to the complexities, conflicts, and contradictions of immersion in academia. According to Angela Dillard, "Nothing captures the intricate and quasi-Byzantine institutional culture of university life as well as the academic novel." ${ }^{11}$ Not only is the excessively complicated nature of university institutions implicated, but also its effects on inter-personal relationships between academics and with students. E.A. Markham's Marking Time (1999) and Barbara Lalla's Grounds for Tenure (2017) have been produced almost two decades apart. Yet, at the core of both texts are deeply introspective accounts of being irrevocably attached to the institutional culture of the university. These texts in particular differ from each other in their wider setting and focus on their respective protagonists.

Marking Time, although set for the most part in England, makes intermittent flashbacks to life as it was in the Caribbean. Implicating the mid-twentieth century era of the Windrush generation which saw Caribbean migrants move to the United Kingdom in search of employment, Markham draws attention to the experience

\footnotetext{
${ }^{1}$ Angela Dillard, "Beating the Clock: Being Up for Tenure Can Make You Feel Like a Criminal", www.nypress.com/beating-the-clockbeing-up-for-tenure-can-make-you-feel-like-a-criminal/.
} 
of a Caribbean academic coming to terms with his diasporic identity. Its protagonist Pewter Stapleton, has to juggle the rigors of marking his creative writing scripts alongside his personal life. Markham, a Montserratian writer who in making the journey from the Caribbean to the United Kingdom would later take up a career as an academic, uses Marking Time as a conduit for his personal experience of being inculcated into a capitalistdriven campus culture. Grounds for Tenure, on the other hand, is firmly set in the Caribbean. In the novel, the protagonist Candace Clarke has to navigate family and romantic relationships while desperately seeking tenure which is jeopardised by academic infighting, nepotism, and the creation of an offshore campus in the Caribbean. Lalla, professor Emerita of the University of the West Indies (UWI), layers the complexity of operating a Caribbean campus with an internal exploration of gendered identity. Grounds for Tenure reveals the vulnerability of the Caribbean university in particular and the Caribbean region in general to global capitalism. Although set in two different regions, both novels engage in similar levels of interrogating Caribbeanness through the campus novel genre.

Functioning as microcosms of the wider Caribbean region and Caribbean diaspora, each novel uses academic settings and characters to not only interrogate academic values and practices but also reflect overarching implications of racism, sexism, and capitalism in academia. By focusing attention to the representation of academia, this paper establishes the valuable contribution by the Caribbean campus novel. Both novels layer socio-cultural critique of academia in a way that enables an engagement with and accountability to the broader history of the Caribbean. Therefore, this paper's meta-academic approach, which in studying representations of academia itself adds to literary scholarship, takes on added significance considering the underexplored field of the Caribbean campus novel.

This paper has two aims. Firstly, it attempts to fill a critical void in Caribbean literature. Although the Caribbean contributions to the campus novel are few, this is no reason for the lack of scholarly attention paid to them. As such, acknowledging and examining at least two novels in the genre is both necessary and overdue. In addition to addressing an underexplored area of Caribbean literature, this paper also aims to make a critical intervention in the purpose and value of liberal arts scholarship in the Caribbean. Through textual analysis of both novels, this paper explores the broader cultural implications of the Caribbean Campus novel. Where Markham and Lalla have served as distinguished professors, their novels hold up mirrors to themselves and colleagues while also giving insights to 'outsiders' about the harsh realities of university life. Both authors speak with a kind of authority that comes with their immersion in faculty-specifically, English faculty. As Angela Hague observes:

In general, the academic novel's author is an insider who sets out to expose the weaknesses of a system of which he is a part, presenting a closed, insulated world populated by faceless students and ineffective, inept, and often corrupt professors. (173)

The protagonists of each novel become self-reflexive agents through which the authors allow us to think about university life. Each text portrays what Robert F. Scott discusses as the campus novel's, "tendency to trivialize academic life and to depict academia as a world that is both highly ritualized and deeply fragmented" (83). In doing so they offer perspectives on the nature of higher education which have further implications for interpreting the society as a whole. This study examines the function of the campus novel to the Caribbean self, and society as well as a sense of the 'global campus,' enacted by the universal problems affecting institutions and the professionals that comprise them. The insider's view that comprehensively exposes the weaknesses of the institution suggests a therapeutic process of community building among academics. As William G. Tierney states, "the novel might be thought of as a way to help academics think about how academic life has been structured, defined, and interpreted in order to create constructive change" (164). Marking Time and Grounds for Tenure emphasize that in spite of the challenges faced by academics, there is still the potential space for strengthening and improvement. Though at times oppressive, the campus is also a site of reclamation and a source of fulfilment for those scholars who can persevere.

The view of universities functioning as microcosms of the wider society is the premise on which this study's interpretation of both novels rest. The academic novel, through its focus on campus culture, is able to interrogate aspects of society that other forms of fiction cannot. Elaine Showalter traces the transformation of the campus novel in the 50s and 60s from being a, "small, enclosed place, but related to the larger society, affected by its values and problems, and even a model of its ideal state" (145), to a 1970s 'darkening' of academic life. "By the 1990s, and through the end of the century," she goes on to say, "the lottery of hiring, political correctness, the culture wars, and the tragedies of tenure had become familiar topics in academic fiction, wearing away the last vestiges of idealism" (107). Marking Time and Grounds for Tenure emphasise 
in their own ways the harsh realities of university life. Markham juxtaposes the never-ending process of marking assignments with his Godot-like perpetual angst of being a scholar while Lalla's depiction of the Caribbean campus in crisis is an extensive exposé on the repeated missteps that impinge on the purpose and integrity of higher education. In Lalla's text, especially where tenure is concerned, the obsession with permanency is more than a desire for security. Rather, it consumes the integrity of the academics, resembling what Tierney describes, that, "academic freedom has been replaced as the central totem of the university by tenure" (175). In Grounds for Tenure, freedom of academic thought is sacrificed for stature.

Both novels rely on satire and parody to mock the reverence for the deeply fragile institutions that they rely on for a living. Using Tierney's characterisation of what constitutes a, "good academic novel," the shared writing style exemplified in each text functions "not [to] portray us as we wish to be seen, but by complicating the picture of academic life, the novels may encourage us to act as we wish to be seen" (176). The academic problems may seem relatively harmless compared to real world problems, but as each author is careful to show, the problems faced by academics are both an effect of, as well as affects, the wider society. Ian Carter's description of "the British university novel as discourse" (10) is used in this study as a way of interrogating the Caribbean imagination, namely what the campus novel represents, the manner of its representation, and the cultural, critical implications of such representations.

The opening of Marking Time introduces the source of Pewter Stapleton's (the narrator) discontent, his "scholarly strain" (Markham 10), as well as establishes the early conflict between him and a former friend. Marking papers uninterestedly corresponds to the general lack of enthusiasm experienced in Pewter's life. The cold and damp setting of Sheffield mimics the harsh marking standards imposed by Pewter. As he debates whether sixty percent is too generous, settling instead for fifty-nine, he invokes the border sharing between Montenegro and Albania to justify that, "for the marker, the assessor, the tin god sitting here, a border is a dangerous thing to negotiate" (10). The politics of border crossing, likened to marking, extends to the politics of departmental conflict:

I thought: clever bastards to escape the academy when no one was looking, congenital Second Markers no more. By now the scholarly strain would have fallen away from their faces: no longer stranded in the demilitarised zone of an old English Department (we're stuck here in between the Koreas, don't you know) or tiptoeing through land-mines (Is that still Angola: will it ever end?) of MPLA and Savimbi the Ugly, the weak smiles attesting to bravery and under fire. (10-11)

Being consumed by academia is exaggerated in its shared turmoil with political upheaval and instability. Yet, according to Pewter, the stress of academia only increases his insatiable appetite: "I find I'm at my most productive when the pressure of marking builds up: suddenly all the fragments start expanding, connecting. Editing ideas start to make sense; it's a good time ..." (15). The double-edged sword of academia demands a sacrifice from those who can create something from the chaos.

In Grounds for Tenure, Candace allows the university to become an appendage to her. Completion of the $\mathrm{PhD}$ symbolises an inextricable bind that proves impossible to sever: "submitting her thesis proved an excruciating release of what seemed to have become a vital organ and left her more hollow than relieved" (Lalla 34). Physiological references to the ties between Candace and the university appear throughout the novel to reinforce the parasitic invasion of academia: "She clung to a deep-set belief in her work, once she could hold onto it, but over the past months, a sense of hopelessness had glided in and begun its insidious coiling under her diaphragm" (44). Throughout Pewter's encounters with adversity he remains necessarily bound by the dictates of the university which gives and takes in equal proportions. As a means of introspection, he marks more than scripts, he also marks his psychological journey, hence the significance of the novel's title. At one point Pewter calls his career, "a race against time" (Markham 54), in a sudden epiphany. His esteem as a writer is called into question as he struggles with issues of failure: "Why so little impact on the life lived: mightn't it have been better, then, to be an Accountant and end up running the university?" (54). Pewter may not doubt the significance of being an academic rather the type of academic one chooses to be. Marking becomes a coping mechanism and his way of working through the self-imprisonment as much as it serves to alienate him from others.

The side effects of being consumed by academia gradually snowballs throughout the novel, causing a schism for the conflicted narrator:

I will force myself to mark faster in future, that way maybe there'll be a bit of time left over for the life. The Life. 
Had to get away. The body was rebelling from the marking. I hadn't marked the scripts, yet ... the mind had long packed up ... Yet this is what's absorbing me; the whole body feels tormented, bruised; the arm hurts. We should demand danger money. No, had to get away. There'll be some moderating of scripts later; and stuff to be selected for the External. And the scriptwriting. But, must get out of here, out of the country, just for a few days. (201)

His resolve to overexert himself takes him further away from self-awareness. The dissociation of his split persona -academic on the one hand 'normal' being on the other- renders his marking ritualistic and mechanical. He continues in spite of its inherent absurdism and despite its reduction of his perception. The other meaning of marking time highlights Pewter's temporal existence. His insistence on marking the time that passes signals an awareness of his own mortality. The play becomes an obsession to offset his mortality by creating something that bears his name, and therefore lasting beyond his death. Randall's preoccupation with completing his book is also an attempt to immortalise himself, and Candace. Pewter, Randall, and Candace all turn to creative writing to provide illumination and order to their chaotic affiliation with the university.

In both novels the underlying sentiments are that academic life is characterised by feelings of discomfort, fear, anxiety, and utter futility. Lalla is far more direct in critiquing the academy. She uses the university setting to explore the negative consequences of dogmatic adherence to the academy. The waiting that Candace must endure following completion of her PhD has implications for her existential waiting for self-fulfilment through academia. She, "had been waiting to be discovered for seven years ... Since the award of her PhD in 2004, each year had been an eternity" (Lalla 6-7). In this chapter entitled 'Headhunter,' Candace becomes the hunted academic as much as she is hunting for a job. The frustrations from, "midnight siftings through universities" (6), is a result of fear that her hard work may not lead to her lofty aspirations:

The thesis that was to open the way to the profession she wanted had closed the door on the way of life that had been hers and had left her in limbo. She dangled in a state of impending loss -waiting, waiting-as the dull ache of unease intensified to anguish and deepened to gloom. (36)

Candace's emphasis on her thesis links her academic success to her happiness. The Godot-esque waiting that Candace must suffer as part of her chasing tenure corresponds to the absurdity of relying on academic accomplishments for self-fulfilment. Her unease at waiting for her academic career to improve is similar to Randall's womanizing as a way of filling his own scholarly stagnation. However, he replaces this unfulfilment with an equally empty addiction. As the narrator says: "His one-to-one encounters seemed to absorb him less, though" (24). When Candace asks him the purpose of his encounters he responds, "For marking time" (240), a phrase that, in the context of the campus genre, unmistakably calls to mind E.A. Markham's novel. And just like Pewter, who uses his playwriting to re-energise his sense of purpose, Randall's book becomes an avenue for compensating his stalled academic progression. Candace's love for linguistics is the same as Randall's writing. As the narrator says: "It was all well and good for Randall to say there were things best fictionalized if one was ever to make them manageable" (213). Both novels depict characters burdened by their individual struggle for recognition as well as the extreme side effects of whole-heartedly pursuing that dream.

As Candace teeters through academic servitude, she ultimately descends into a suicidal state when her reality doesn't measure up to her expectations:

On some level of consciousness, she steadied herself and examined her rage, tugging it into a line of reason. After all, to reject the concept of suicide because of a belief in God made sense, but to believe in God so as to avoid suicide was weak-spirited and dim-witted. (310)

Being the meticulous researcher that she is, Candace negotiates the contemplation of suicide as she would a job contract. Candace's reputation of being a successful academic entails coming to terms with the loneliness of her profession, but she embraces it in spite of the impending misery she knows it harbors. Pewter is also engaged in a negotiation where he rationalizes the sacrifices demanded by academe. His desire for escape makes him an academic wanderer in the university as well as the wider society. Unlike Barbara Lalla's Grounds for Tenure whose setting is restricted exclusively to the geography of the campus, Markham departs from this convention of the campus novel by showing that his external conflict is impacted by affairs related to academia, but not necessarily bound by the walls of the university. Thus, the narrator's travails include 
visits to parts of Europe, America, and a return journey to the Caribbean. In doing so, his stark realisation of the changing face of London's telephone etiquette is an example of his isolation among fellow academics and from the outside world:

Balham's ansaphone said he was out, and asked to state the time and day of the call. That seemed funny, not funny that Balham now ran to an ansaphone, but the nature of the message on it, the explicitness of there being no one at home: what had suddenly made people in England so laid back? (Markham 32)

The changing face of London is juxtaposed with the changing values of campus life: the banality of 'new' research, the struggle for tenure, competition among academics, and childish communication between administrators.

Pretence rears its ugly head in Marking Time where the protagonist is forced to compete with his 'nemesis', Carrington, who, "changed his name to that of a district in London, gaining gravitas" (9). He is forced to admit of him: "Like me he worked in Cultural Studies in a new university and that's why, in a sense, he is my enemy: that's one reason I like to think I mark differently from him" (9). But like his competition, who, "used to enjoy this job, of marking, the sense of power" (9), so too does the narrator use marking to invigorate him with purpose and his life with value. And like Carrington, whose desire to derive power and status from being in control ensured he remained, "a sad man but no sadder than anyone else" (9), the narrator similarly has to endure frequent pangs of emotional isolation and estrangement from others. Marking scripts, in addition to reinforcing hierarchies between students, also functions as a method of competition among academics. It further operates as a, "cleansing ritual," which makes him less malicious (18). The extent to which this is actually true is contradicted by the narrator's teetering between poles of intellectual supremacy and emotional dissonance. This is represented in the title he uses for the play to equal Carrington's own writing career; Between a Rock and a Hard Place.

As the environment gets more competitive, as more academics enter the fray, the modus operandi is less about solidarity and more about survival. It sets each academic against the other in a rat race to produce papers that will grant them supposed prestige and ultimately promotion. At end of the chapter entitled 'The Road In,' the scholarly ideals that Candace valued so highly make way for an instinctual fear of losing what she has already achieved. Professor Critchlow's riddle involving the disparity between the lack of time and the demand for cumulative production increases the insecurity Candace feels as a scholar causing her to panic: "Then she thought about how all she wanted was to survive, and she told herself: Stay invisible" (Lalla 73). The competition that fuels the motivations of the scholars are not constructive in the sense of inspiring each person to become better or to push the limits of research beyond their comfort zone. Rather, their egos conflate healthy competition with a territorial instinct to hold on to what they have, leading to an air of secrecy shrouding notions of truth and community. They compete for competition's sake, estranging themselves from what exists beyond the confines of the campus. To Candace's observation that Francine, "takes everything personally ... as if she just goes for interpersonal conflict," Sonja replies "Like an addict for cocaine" (132).

Competition becomes a drug for the scholars. It clouds their sense of rationality and evokes their darkest compunctions. Candace realises that their competitive nature does not result in production, but rather impedes it; the academics revert from the university's mandate of being interactive with the wider society and instead resort to infighting as they become increasingly self-indulgent and restrictive. According to Wright in his conversation with Candace however, it is not about struggling to get in, but rather to get out: "Tenure," she said. "Or rather, lack thereof. Everyone is slicing up everyone to get ahead - and where do I fit in?" "Perhaps you are asking the wrong questions," he reflected hopefully. "You may need to be thinking of how best you can wriggle out" (218-19).

The momentary jolts of realisation concerning the harsh realities of academia make Candace consider, albeit for a fleeting moment, a career change. It is in these moments that the drug of academic involvement and its addictive nature are reinforced:

Impossible. Academia, she admitted to herself, does more than get under one's skin: it recalibrates the mind as surely as a drug interferes with brain function. Of course, a career change had occurred to her from time to time, but it was no use: the craving for the intellectual life made her unfit for any other. (143)

Candace considers Wright's summation, but at this point is already indoctrinated in the extremely competitive and politicised culture of the university: "in between those fractures in academic relations ran a differ- 
ent pattern: a counter-force shifted alignments among lecturers ... And some of these interfaces destabilized professional life. Unsteady connections mushed into a slough of rancour and favouritism that mired even those trying to stay clear of the center's politics" (188). John R. Thelin and Barbara K. Townsend highlight the campus politics theme as central to the genre noting that, "novels about faculty and administration expand, elaborate, and interpret this theme so as to bring the observation to life" (207).

Pewter's obsession with writing a play to rival Carrington's mimics his perpetual feelings of unfulfillment and inadequacy. Just as Lee suggests that Pewter, "was suppressing something more profound than distrust of Balham" (Markham 253), so too do Pewter's conflicted feelings go beyond Carrington, pointing instead to an internal struggle. The narrator's angst is made palpable by the conflict of both loathing and depending on Carrington: "In all this I was trying with my own schizophrenia of damning Carrington and all his (many) works and at the same time using him, hopefully, to further my career" (17). "In this way he becomes an appendage of Carrington" (134), more like him that he would could have imagined. His inferiority complex is compounded by his role of editing a book by Carrington, the man who, "naturally laid claim to the Americas" (33). Markham uses the academic practice of editing someone else's work to express his character's internal conflict: "To edit someone's work is to acknowledge that person as primary and yourself as secondary" (17). Just as the narrator exerts his superiority over his student via the act of gradually marking down the student's score, so too does his editing of Carrington's work enforce its own hierarchy. Marking and editing operate as metaphors unique to the academic world which consolidates the identity of the campus novel genre.

The relative burden of academia weighing down on Pewter and his colleagues culminates in the feeling of entrapment experienced by the narrator. It makes him irritable and hyper-sensitive to any stimulus causing the slightest discomfiture, such as his clothing: "Downstairs I'm trapped; trapped in my overcoat, nothing on underneath, but shoes, laces not done up, and a bag of rubbish in my hand" (49). Here, David Lodge's argument that the campus novel, "belongs to the literature of escape" (33) is apt. Pewter's feelings of a, "vague sense of disorientation and feelings of displacement (51-52), are compounded by his sustained connection to the university and its people. Again, the act of marking is used as a metaphor to describe his state of mind: "Going away (like marking) has always been a productive time for me" (202). The paradox is that while likened to therapy, marking is both the source and saviour of his discontent. He confesses earlier that, "Marking was my end of the line" (100). It opens up spaces as much as it closes them. Where feelings of entrapment and the subsequent desire for escape is a pervasive trope in postcolonial literatures, the angst of being an outsider in England is coterminous with his academic isolation: "But it was a disorienting time when the new family, the new home, the new life stubbornly refused to take shape. I moved back into the old house in Long Lane, in Finchley and there was a sensation of moving back" (165).

By engaging with Pewter's former life on St. Caesare, ${ }^{2}$ Marking Time is also in part a novel of return. This interplay between past and present occurs later in the novel and as part of Pewter's introspection:

So what was to be done, to coin a phrase? Was this the end of the line? How can you have lived in a place for so long and not be rooted, settled? At the back of our minds (and not always at the back) was the promise, the temptation of one last move which would make final sense (sense, finally) of the journey. My mother's journey had made no sense, no sense. (166)

Tropes of rootlessness, failed journeying, despair, and the spectre of unfulfillment, ubiquitous to Caribbean migrant fiction, reappear here in a novel that begins with a focus on the campus and gradually widens its lens. In the same way that the university is established by the novel as subtly exclusive, so too does imperialism deny inclusivity. Self-professed as, "a man of dubious provenance" (130), Markham further establishes Pewter's dislocation. Pewter goes on to admit: "We used to think, coming from St. Caesare, that we had the best of both worlds, two languages. But England and France did their best to deny us those languages" (166). Though returning to life in St. Caesare is discouraging, Pewter takes comfort in the fact that, "England hadn't yet deprived us of memory, of Coderington, our frozen bits of then" (183). Similar to Balham who, "was

\footnotetext{
2 St. Caesare, according to Markham, is somewhere, "off the coast of Montserrat" ("A Short History of St. Caesare" 116). In this article, Markham writes a history of an imaginary island. As a citizen of Montserrat, a British Overseas Territory, he understands the complexities of occupying the periphery. Thus, he goes on to state that St. Caesare,"had to be close enough to a larger island to make its political status ambiguous" (116), and that, "St. Caesare would be spelt differently from the village in the south of France (St. Cezaire) to show colonial distance" (118). The political plausibility of a postcolonial island that Markham must address in order to validate his imaginary island serves to magnify the perspective of Pewter whose memories of St. Caesare frequent his introspection of his role as an academic.
} 
concerned with Arts administration and with decolonization" (196), Markham's creation of St. Caesare and Pewter's remembrance of it is an act of denying colonial hegemony because through memory it is kept alive.

In Grounds for Tenure, Candace Clarke is an ambitious scholar at the University of the West Indies. First person narration makes up the Prologue to the story. It introduces the two motifs central to the story: the angst of uncertainty and the necessity of writing in order to work through the external and internal conflict. With references to a shaky existence abound in the novel, the narrator from the outset makes the critical distinction that, "this book rests on bedrock" (Lalla 1). Bedrock, being consolidated rock, is solid and tightly bound. The implication here is that the novel-and by extension the act of writing-is more reliable than the selfish competition among scholars for unashamed success. The Prologue itself contrasts with the rest of the novel. The inflated scenes concerning scholarship that are rife with pretence and uncertainty stand in opposition to the candor and directness contained in the Prologue. Grounds For Tenure begins with the evocation of a pervasive rootlessness: "Watch me. It have no such thing as solid ground" (1). As with Candace's general feelings of being in perpetual limbo, the university is likewise tainted by uncertainty. The institution is caught between administrative obligations and its mandate to creating opportunities for learning and the advancement of research: "The whole bureaucracy for admissions, examinations, appointments and promotions-and tenure, most of all for tenure-stifled creativity at every level (6). It has repercussions for further stagnating the academic environment as, "The lingering throughput of doctoral candidates well outpaced staff turnover" (56).

In the corporatisation of academia, the mission of the university becomes more about producing qualified, not occupied, personnel. The over-supply of academics results in the competitively hostile environment where merit is applauded, but unscrupulousness pays. There is the manifestation of a conflicted ideology at it relates to the role of a higher education institution. It results in vicious rivalries with self-serving interests that each diverges from the unifying purposes of a university, and a Caribbean one at that. So while Francine preaches on the, "larger issues" such as "the needs of the community, the discipline and its interplay with other disciplines [we cannot condone tunnel vision here] and, also, the profile of our institution itself" (128-29), the academics enact a tribalism that belies their claim to solidarity and community. It results in a fractured support-system where Candace chooses to build her future. This is the double entendre inferred by the title.

Throughout the novel Candace is constantly trying to assert her qualifications by attempting to secure employment and eventually tenure in a thankless profession. Parallel to this is her search for an even ground both physically, in terms of migration, as well psychologically, in her attempt to balance her career and personal life. There are various references to Candace being on unsettled ground which correspond to the overarching narrative of instability signalled by the title of the book and played out during the course of its events. The novel is an attempt to, as the narrator says, "assemble from fragments that came slowly and untidily together" (356). The extended metaphor of academe being built on shaky ground takes on literal proportions when there is an actual earthquake. Earl Rider's death during the earthquake is didactic for the ways in which it signals the ultimately futile attempts at chasing tenure. At the end of the novel, Candace abruptly leaves the funeral. The metaphor of disaster is revisited to describe the crumbling Institute and the void facing the people: "Candace's departure reverberated in an aftershock of silence" (360). Her exit is anticlimactic, but it does suggest a lesson has been learnt. At this point she is finally able to escape the other academics, burying her traumas with Earl Rider's body.

Marking Time also contains references, though to a lesser extent, of being uprooted. It is obvious in Pewter's itinerant vacillation between St. Caesare and London, in his memoried returns, and in his desire for escape. Pewter expresses in more overt terms his own feelings of uprootedness when he asks himself, "How can you have lived in a place for so long and not be rooted, settled?" (Markham 166). His inability to be grounded in his relationships and career resembles that of Candace who throughout Grounds for Tenure is unable to find emotional grounding to consolidate her academic aspirations. Candace suffers a pervasive loneliness summed up in her unease at fitting it. Native to Jamaica, but employed in Trinidad, "She had never grown to feel at home in Trinidad" (Lalla 8). Her physical dislocation is countered by the sense of belonging she derives from belonging to the university to the extent on par with a nationality: "but if she was not Trini to the bone, as the locals expressed it, nor was she exclusively Jamaican any more. She was UWI in the marrow" (38-9). Just like Pewter who feels restless in London and therefore has to 'escape', Candace portrays a rootlessness that is synonymous with the wavering ground of her academic career.

Yet, undergoing "an entirely new form of separation trauma" (34) Candace is unable to divest her interest in academia because she has so heavily invested purpose and meaning into it. Randall's advice is similar to that given by Wright, but no more heeded by Candace: 
You'd rather no dwell on that, but better to think your way through and beyond it than have it haunt you for life. So Randall encouraged her to strip off whatever protective layer she had evolved. It's a wound, to clean before it festers any more.

Yet what did he know about how deep it went, or of the miasma curled beyond the brim of sleep to mist down, seep in and fill the spaces in her throat, lungs, belly, limbs, dulling thought and sensation. (250-51)

The ubiquitous trope of the wound of history that pervades Caribbean literature reappears in Grounds for Tenure under the theme of campus politics as Candace tries to dictate her own path to success rather than have it predefined by her father: "A sliver from her father's disavowals had long worn its way into her, deep and visceral, and it shafted her every time she encountered him" (66). Her wound with, "her brain haemorrhaging its past" (267).

The spectre of history is cast by her father, Earl Rider, whose career path resulted in neglect of his familial commitments in order to seek personal advancement. Earl becomes representative of the colonialized intellectual who scorns his Caribbean scholarship. He, "raised his voice above David Rudder's "Calypso Music" (23), as a symbolic gesture of disdain for anything related to the Caribbean. Earl offers to fund Candace's research on one condition:

He pointed out the advantages of her doing her graduate work right there at TCAC (Texas College of Arts and Culture), where she could stay with him at no cost, but when she asked point-blank whether he would help finance her graduate programme at UWI, he refused. He was only prepared to support her at TCAC. (24)

Earl Rider is the post-colonial subject suffering from an inferiority complex where to have any association with the Caribbean is considered to be 'less-than'. As the Provost, Earl Rider's personal views indirectly influence the direction of the Caribbean university. Amidst talk of privatisation of the university, the academics discuss the annexation of the UWI to another campus as well as the expansion of its Mona campus following the establishment of, "a colony in they so-called Western Campus" (137). Another one of the academics, Harvey Balham, weighs in on Rider's despotic leadership: "policy? Rider runs this place like a plantation ... He responds according to his own agenda and on a case-by-case basis. Procedures? You think this is an institution of higher learning, or what?" (89). Balham's rhetorical question at the end undermines the purpose of the university and the method of leadership that causes it to become chaotic. Rider's corrupted leadership resembles David Lodge's analysis of the statement made by F. M. Cornford (1912), that, "the academic exercise of power consists almost as much in exploiting the democratic system of university government to frustrate others as in advancing oneself" (qtd in Moseley 263). The relationship between power struggles among academics has implications for university governance which ultimately affects everyone associated in any way with the university.

Earl Rider plays the role of the most unscrupulous, ruthless, and self-serving character. Where Angela Hague makes the claim that, "the villain of the piece [the campus novel] is almost without exception the professor himself" (173), Grounds for Tenure establishes Rider as precisely that. Described as "a law unto himself" (205) he is ironically the most outwardly successful. Rider's competitively selfish impulses, however, alter his personality as he devotes scholarly pursuits to his quest for power, sacrificing his personal relationships, most of all with his daughter Candace. Her love-hate relationship with academia is born out of a tempestuous relationship with Earl Rider:

However lightly Candace spoke, she held at bay a beast materializing in her thoughts and straining against control. It had been one thing learning to avoid her father after years of unrequited longing. But now here was Sonja viewing him as a charlatan who enabled students to engage in academic fraud so as to extend the list of completed doctorates on his $\mathrm{CV}$, or even in return for actual favours. His shape-shifting literally sickened her ... acknowledging to herself that he fitted somewhere in a scale of unprofessionalism, ignorance, negligence, compliance, collusion, fraud by fabrication or plagiarism. (268)

Candace's sense of her achievement and herself as an academic is challenged when she has to juggle her affection for Randall, her sympathy for her mother, and dislike of her father while competing for job security at the university. With an estranged father and a disconsolate mother Candace finds, "her own, secret, 
space" (13), in books and later the university to replace her parental void: "The university had more idea of parenthood than Earl or Patrice, Candace complained to Randall" (20). As she would soon find out however, the university is profoundly unforgiving and unsympathetic to Candace's personal and professional goals.

Both novels depict characters who must look inward and therefore away from the university for solace from the rigours of academe. The extent of introspection undertaken by the protagonists of each novel results in both of them breaking the fourth wall. Marking Time and Grounds for Tenure depict scholars genuinely in love with literature, but caught in a world of academic cutthroats. Writing brings both pleasure and pain as they rely on documenting their experience as a therapeutic exercise in resolving their inward anxiety. Just as marking scripts is Pewter's way of working through his, "scholarly strain" (Markham 10), Candace finds solace in Literature and Linguistics: "for she felt at home once she retreated into her head, usually by way of a book" (Lalla 9); "Words, sentences-she unwrapped them greedily, sense after sense. It was her own, secret, space" (13). As readers are advised from the very first page: "[those] uninterested in scholarly observation should skip to chapter 1" (1). Grounds for Tenure resembles a memoir that traces the journey of Candace through academia. But told in the third person, Candace is as much the subject of narration as she is an object placed within the wider milieu of issues: Caribbean creativity and scholarship, gender, and disillusionment. Domestic images, reinforced by Candace's mother, bring back Candace to reality and the mundane: "Outside she had been in charge of the battle. The contrast illustrated by the two descriptions of the control she has sets up the tension between the sense of pride Candace takes in being an academic and the anxiety she feels as a woman surrounded my traditionalists:

Among them were those who thought a young girl should be learning the household, busy with pot spoon or needle and thread ... Certainly not the reading of thick books of verse or novels from every age, not that avid sort of reading in which the child submerged so deep that she came back out with her eyes wide and dark. (10)

Books, and by symbolic extension education, is the motive force that guides Candace out of the stereotypical expectations placed on her. Competition in academia is the escalated attempt to assert her individuality as a pathway to her self-realisation. However, the competition is driven by something instinctual which further serves to contextualise the university's sense of purpose and loss of its direction. Candace grapples with these issues as she moves through the ins and outs of academic life. She along with Randall eventually find support, but only when they escape the obligations that campus life demands. In between meeting and lecture Candace is at ease. Once inside the lecture hall however, her discomfiture resurfaces: "Feeling jumpy at irritable, Candace ducked out of an evening meeting so as to drive over for a public lecture. The university's grounds and the presiding mountains comforted her, but at the lecture, she glimpsed few faces she remembered" (188). The narrative is informed by Candace's chosen field, despite her parents' wishes, ${ }^{3}$ of Linguistics and Literature. Like Pewter who is preoccupied with drafting the play, Candace, also a literary scholar, is 'most concerned with plot' (1) as part of her methodological approach to writing her story.

Writing becomes a self-reflexive activity that the protagonists rely on to mediate their academic anxieties. The Prologue of Grounds for Tenure establishes the act of meta-writing as grounded while the events in the novel are centred on themes of solitude, insecurity. It bears the weight of a scholarly environment consumed by a sense of vicious competition and self-disillusionment. In Marking Time, meta-writing takes the form of Pewter working through his 'scholarly strain' via his playwriting. Julie Cruikshank in her study of narrative practice finds that, "a story can reframe issues by providing a larger context" (4). Through storytelling, the protagonists of both novels establish their identities and find themselves. This can only occur when there is either physical or emotional distancing from the campus itself. While Pewter is able to reassemble the fragments of his identity through devotion to his play, Candace is trapped in the snare of campus life because the PhD becomes her saving grace and means of escape from her dysfunctional family. Much of her personality is constructed through her love for writing and the word. Her guarded disposition is characterized from her reluctance to readily entertain Morgan Shade, even if he had a, "carefully preserved accent", because, "a

\footnotetext{
${ }^{3}$ We are told that the mother's salary, "covered the books and entitled her to hold forth on Candace's choice of programme. Linguistics? What is that? And English? But you not serious Candace ... You have the grades to do law. Bad enough you refuse to choose the sciences in school. You could have got into med school easy, easy. But no - you cling to these arts subjects, and now, with a string of As, you refuse to do the law. And where you will get to with an arts degree? Into some paltry teaching job. I can't believe you have so little ambition" (16). The mother's denouncement of an arts degree being exemplary of lacking ambition highlights the earliest source of Candace's anxiety as an unfulfilled academic.
} 
few warmed-over diphthongs were not enough to win around Candace" (3). According to Pewter, Carrington, "use[d] writing to point out the clichés they held in real life. It seemed to me that what he had been doing in the seminar was to legitimise one such cliché, and we argued about that" (Markham 139). It isn't lost on Pewter, the irony that Carrington becomes the very cliché that he encourages in others. Markham also reinforces clichés about academics and students alike through his campus novel genre. In Part ten of Book three, Markham's voice rings clearly when Pewter, forsaking the play he has attempted, turns to prose, the reason being that, "The novel could rescue all those sorts of things that were lumpy and sketchy on the stage" (241). The narrator's search for the precise form for his story coincides with his reconciliatory journey that seeks to address his formlessness at being an academic, and a postcolonial subject. A few pages in later he says:

But reality breaks in. January 1990. Berlin. Balham and I are conscious of so many single, black men drifting through the city, looking lost, making deracinated seem more than a faded, slightly pseudish abstract term: we were, partnerless, contributing to that image. (245)

The racism projected onto them by others as much as themselves motivates Pewter to conceptualise a different kind of public space using what is most familiar to him, the university. Based on his unexpected void from being an academic, Pewter attempts to formulate a much more forgiving model of the university as open space. His colleagues find his idea "poetic" for its romanticism of university life and the roles that people play as part of it. In his mind, universities should not be, "the private oases of privilege they once were" and that teachers, administrators, and others, "were the curators of the national heritage" (236). As a postcolonial migrant, Pewter resolves that the year 1990, "must be the decade of the black man as arts administrator, etc." (246). Race, history, and colonialism coalesce against the overarching and endless competition among academics and the subsequent fight for prominence.

Grounds for Tenure also depicts a discrepancy between what is real and imagined. As a result, the scholars' experience of working for the university resembles a simulation of reality. It is something Candace is aware of, but nevertheless embraces: "This idea of being part of a fantasy faculty was unnerving but confirmed by day to day experience ... Communication between academic staff and management ... remained cosmetic" (Lalla 149). Lalla's repeated associations of the university with consumerism, corporatisation, and fantasy suggests a belief in research as being empty, lacking substance, profiteering, and concerned with appearance. As a result, scholarly interest in science fiction and postmodernism is fashionable, and therefore marketable in the academic environment of Grounds for Tenure. Caribbean research becomes a commodity to invite interest to the region and not necessarily for its own benefit.

In many ways, Candace is similar to Pewter. Both challenge and question the academic world of which they are a part. Candace differs in her affection for academia and as a result still believes in the potential for productivity, whereas Pewter, a more seasoned academic, is disillusioned to the point of indifference. And whereas Candace and Randall often become disenchanted with the warped academic values and pressures, Pewter remains able to weave in and out of the restrictive environment by eventually coming to terms with his responsibilities and purpose as a Caribbean scholar. Markham and Lalla situate their critique of academe within a broader culture of stifled production and consumer culture. Both authors advance their treatment of academia in different ways. In Marking Time, Markham incorporates the wider, non-academic community by having Pewter escape; first the confining association of marking scripts and then his perceptual returns to St. Caesare. By tackling issues related to race, sexism, and institutional inefficacy, Markham's social conscience attempts to be as extensive as his critique of academia. The description of Pewter's most menial duties, such as going to the laundromat or visiting the London Library to renew his subscription, are set against the more serious tasks of marking scripts and writing his play. The juxtaposition creates the effect of extending the supposedly high esteem of the academic to the seemingly mundane. In the process of completing his private and academic responsibilities, Pewter resolves the scholarly strain that threatens his epistemological crisis.

Both Marking Time and Grounds for Tenure illustrate situations where the university's failure to incorporate the public overwhelms and eventually runs counter to its proposed aim of inclusivity. The novels highlight the dangerous reality that results from the estrangement between the university and the wider community and also the self-alienation experienced by the academics themselves. While Markham's novel is focused on the private journey of Pewter, Lalla amplifies satire by applying it to the entire academy. In each way, both novels draw attention to individual and collective academic spaces that encapsulate a lost sense of itself and of its purpose. The characters of the novels become interpellated into the corporate culture of the academy. They also act as cultural reflections of the region and its diaspora. As such, these campus novels 
offer more than textual analysis. Markham and Lalla contribute to the questioning of what kind of Caribbean and what kind of world through the depiction of problems afflicting the Caribbean intellectual. These problems include feelings of rootlessness, alienation and being racialized. The novels portray academic communities as struggling because the individuals themselves are unable to come to terms with their own place in the university and their purpose as academics. This paper's examination of each author's portrayal of academia attempts to develop the underexplored genre of campus fiction. In addition to acknowledging the significance of campus fiction in Caribbean literature, this paper highlights the relevance of liberal arts studies to the university. As microcosms of the Caribbean, the universities under scrutiny enable an interrogation of the Caribbean and its diaspora. Both texts engage in a socio-cultural critique of the fragile yet damaging perception of the liberal arts scholar as isolated and irrelevant. By opening the exclusive space of the university, each author bridges the gap separating the institution and the wider society. In the process of encouraging a renovation of the university so that it can share in rather than distance itself from the society in which it exists, the novels bring us closer to understanding the campus as it has been, and how it is currently conceived. The campus novel proves to be a critical, notwithstanding satirical, lens to enable reflections of not just the Caribbean campus, but the Caribbean region and its diaspora.

\section{Competing Interests}

The author has no competing interests to declare.

\section{References}

Carter, Ian. Ancient Cultures of Conceit: British University Fiction in the Post-War Years. Routledge, 1990.

Dillard,Angela. "BeatingtheClock: BeingUp forTenureCan Make You Feel LikeaCriminal." NYPress, accessed 22 Jan 2020, www.nypress.com/beating-the-clock-being-up-for-tenure-can-make-you-feel-like-a-criminal/.

Hague, Angela. "The academic world in modem literature." Midwest Quarterly, no. 26, vol. 2, 1985, pp. 171-178.

Lalla, Barbara. Grounds for Tenure. UWI Press, 2017.

Lodge, David. "Robertson Davies and the Campus Novel." The Academic Novel: New and Classic Essays, edited by Merritt Moseley, Chester Academic, 2007, pp. 261-267.

Markham, E.A. "A Short History of St. Caesare." Writing Ulster, no. 1, 1990/1991, pp. 112-127.

-_-. Marking Time. Peepal Tree, 1999.

Scott, Robert F. "It's a Small World, after All: Assessing the Contemporary Campus Novel." The Journal of the Midwest Modern Language Association, vol. 37, no. 1, 2004, pp. 81-87. DOI: https://doi. org $/ 10.2307 / 1315380$

Showalter, Elaine. Faculty Towers: The Academic Novel and Its Discontents. Oxford UP, 2005.

Thelin R. John, and Barbara K. Townsend. "Fiction to fact: College novels and the study of higher education." Higher education: Handbook of Theory and Research, vol. 4, edited by J. C. Smart, Agathon Press, 1988, pp. 183-211.

Tierney, William G. "Academic freedom and tenure: Between fiction and reality." Journal of Higher Education, vol. 75, no. 2, 2004, pp. 161-177. DOI: https://doi.org/10.1080/00221546.2004.11778901

How to cite this article: De Matas, J 2021 A Scholarly Strains on Shaky Ground: Caribbeanness and the Campus in Marking Time and Grounds for Tenure. Anthurium, 17(1): 11, 1-11. DOI: https://doi.org/10.33596/anth.388

Published: 01 September 2021

Copyright: ๑ 2021 The Author(s). This is an open-access article distributed under the terms of the Creative Commons Attribution 4.0 International License (CC-BY 4.0), which permits unrestricted use, distribution, and reproduction in any medium, provided the original author and source are credited. See http://creativecommons.org/licenses/by/4.0/. 